\title{
Forecasting the number of cases and deaths from Covid-19
}

\author{
Aldona Migała-Warchoł, Monika Pichla
}

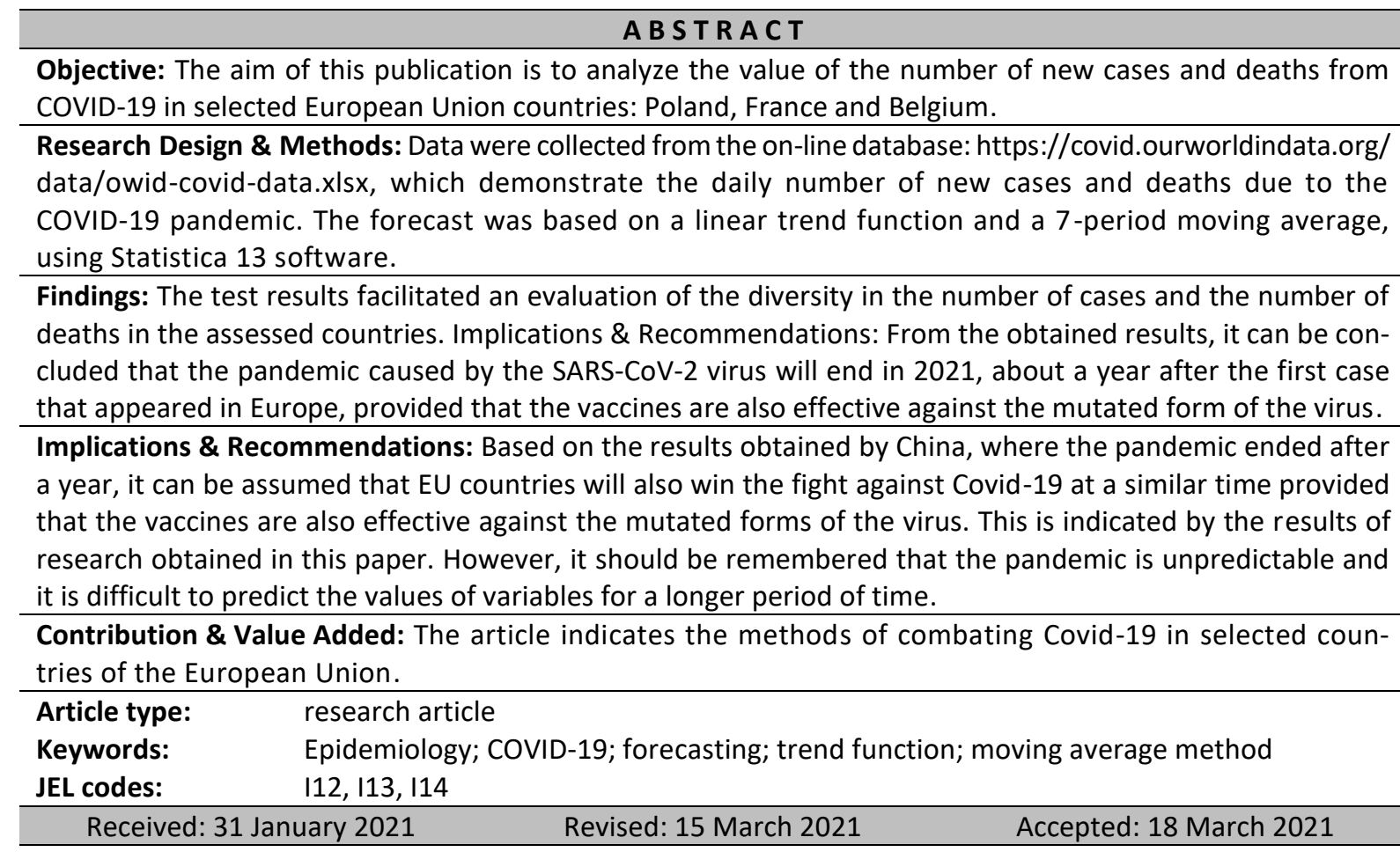

Suggested citation:

Migała-Warchoł, A., \& Pichla, M. (2021). Forecasting the number of cases and deaths from Covid-19 in Belgium, France and Poland. International Entrepreneurship Review, 7(1), 73-82. https://doi.org/10.15678/ IER.2021.0701.06

\section{INTRODUCTION}

The previous year has turned out to be the year of fighting the new and deadly virus. Around the beginning of spring 2020, almost the whole Europe has been affected with the novel coronavirus outbreak. The Severe Acute Respiratory Syndrome Coronavirus 2 (SARS-CoV-2), which causes the disease called COVID-19 was reported for the first time in Wuhan, Hubei Province, China, in December 2019. Since then, it has been spreading worldwide. Due to the manifestation of a wide range of symptoms - from asymptomatic or mild to severe and deadly - this airborne virus has paralyzed the whole world (Esakandari et al., 2020). World Health Organization (WHO) declared the pandemic on 11th March 2020 (Chun, Baek, \& Kim, 2020). The pandemic has brought about many changes in the lives of Europeans as well as those of other continents.

Coronaviruses are enveloped, positive-sense single-stranded RNA viruses that infect humans, but also a wide range of animals. Coronaviruses were first described in 1966 by Tyrell and Bynoe, who cultivated the viruses from patients with common colds (Tyrrell \& Bynoe, 1966). Based on their morphology as spherical virions with a core shell and surface projections resembling a solar corona, 
they were termed coronaviruses (from Latin: corona = crown) (Velavan \& Meyer, 2021). Among the seven subtypes of coronaviruses that can infect humans, the beta-coronaviruses may cause severe disease and fatalities, whereas alpha-coronaviruses cause asymptomatic or mildly symptomatic infections. SARS-CoV-2 belongs to the $B$ lineage of the beta-coronaviruses and is closely related to the SARS-CoV virus (Bedford \& Hodcroft, 2021; Zhou et al. 2020). Coronaviruses are common and cause variety of diseases, mainly respiratory, hepatic, enteric and neurological. The world has been already two times hit by the epidemic of coronaviruses - severe acute respiratory syndrome coronavirus (SARS-CoV) in 2003, with fatality rate of $10 \%$ and Middle East respiratory syndrome coronavirus (MERS-CoV) in 2012, with $40 \%$ morbidity (Jiang et al., 2020).

The aim of this publication is to forecast the value of the number of new cases and deaths from COVID-19 in three selected European Union countries: Poland, France and Belgium. We will make a prognosis of the number of new cases and COVID-19-related deaths in Belgium, France and Poland. Moreover, in the article were compared the stringency indexes of selected European countries at the time of the onset of the peaks and with the overall impact of COVID-19 on the number of new cases and COVID-19-related deaths.

The article starts with the literature review (on the impact on the pandemic of the economy as well as on the coronavirus itself), which is followed by the material and methods section explaining the applied research methodology. The main part of the article is included in the empirical findings section. The article ends with the final conclusions.

\section{LITERATURE REVIEW}

The scientific literature emphasizes the fact that, unlike previous crises, the Covid-19 crisis has many dimensions. In order to limit the spread of the pandemic, the governments of countries decided to confine millions of people to their homes (Kinnunen et al., 2021), which turned out to be an effective way to slow down the increase in few infections, but it brought significant economic costs, such as a collapse of many enterprises or the depletion of a large part of societies destitute (Żak \& Garncarz, 2020). The current pandemic is very challenging for the whole economy (Lipkind, \& Kitrar, 2021), for its sectors and industries (Marona \& Tomal, 2020) or for businesses, especially family firms (Marjański \& Sułkowski, 2021).

At first, it was hard for everyone to believe that life could change like this in the context of fighting the virus. However, the immediate spread of SARS-CoV-2 has forced many countries to shut down in order to curb the pandemic. A broad spectrum of governments' responses has been observed. The most common restrictions include travel bans, prohibition of gatherings, closing of schools and other public places e.g., cinemas, shopping centres, gyms etc., as well as contact tracing and subjecting people to quarantine (Cheng et al., 2020).

For example, the Polish government introduced restrictions on economic activity, as well as in the social life of the inhabitants of Poland. Of course, there have been changes in these restrictions.

The following restrictions related to COVID-19, called the 'first lockdown', have been introduced in Poland. The stages of changes in the restrictions during the first lockdown in Poland are listed in Table 1.

During the second lockdown in Poland (from November 7, 2020), the following restrictions were introduced:

- cinemas, theatres, museums and other cultural institutions have been closed,

- hotel facilities are available only to people on business trips,

- distance learning for children in grades 1-3 has been introduced,

- in stores up to $100 \mathrm{~m}^{2}$, trade can be carried out in the following way, there may be 1 person per 10 $\mathrm{m}^{2}$, and in stores over $100 \mathrm{~m}^{2}, 1$ person per $15 \mathrm{~m}^{2}$,

- shops in shopping malls are closed, except for grocery and service shops, i.e., pharmacies and drugstores,

- a ban on meetings and events has been introduced,

-1 person per $15 \mathrm{~m}^{2}$ may stay in churches. 
Table 1. Stages of changes in the restrictions during the first lockdown in Poland

\begin{tabular}{|c|c|c|c|c|}
\hline Dimension & STAGE I & STAGE II & STAGE III & STAGE IV \\
\hline $\begin{array}{l}\text { Economic } \\
\text { activity }\end{array}$ & $\begin{array}{l}\text { New rules in trade and services } \\
\text { (up to } 100 \mathrm{~m}^{2}-4 \text { people for } 1 \\
\text { cash desk, over } 100 \mathrm{~m}^{2} 1 \text { per- } \\
\text { son for } 15 \mathrm{~m}^{2} \text { ). }\end{array}$ & $\begin{array}{l}\text { Opening DIY } \\
\text { stores on week- } \\
\text { ends. Opening ho- } \\
\text { tels and other ac- } \\
\text { commodation fa- } \\
\text { cilities. }\end{array}$ & $\begin{array}{l}\text { Gastronomy - station- } \\
\text { ary with restrictions, } \\
\text { opening of hairdressing } \\
\text { salons and beauty sa- } \\
\text { lons, opening stores in } \\
\text { shopping malls. } \\
\end{array}$ & $\begin{array}{l}\text { Opening massage } \\
\text { salons and solari- } \\
\text { ums. Allowing } \\
\text { the activities of } \\
\text { gyms and fitness } \\
\text { clubs. }\end{array}$ \\
\hline Social life & $\begin{array}{l}\text { Lack of possibility to move for } \\
\text { recreational purposes (social } \\
\text { distance and covering the } \\
\text { face). Forbidden access to for- } \\
\text { ests, parks, and playgrounds. } \\
\text { Religious worship } 1 \text { person per } \\
15 \mathrm{~m}^{2} \text {. Exclusion from re- } \\
\text { strictions on the movement of } \\
\text { non-adult persons over the age } \\
\text { of } 13 \text {. }\end{array}$ & $\begin{array}{l}\text { Opening some cul- } \\
\text { tural institutions: } \\
\text { libraries, muse- } \\
\text { ums and art gal- } \\
\text { leries. }\end{array}$ & $\begin{array}{l}\text { Sports events for up to } \\
50 \text { people (in open } \\
\text { space without audience } \\
\text { participation) Organiza- } \\
\text { tion of childcare in } \\
\text { nurseries, kindergar- } \\
\text { tens and in school } \\
\text { grades } 1-3 \text { - deter- } \\
\text { mined max. number of } \\
\text { children in the room. }\end{array}$ & $\begin{array}{l}\text { Theatres and cin- } \\
\text { emas under the } \\
\text { new sanitary re- } \\
\text { gime. }\end{array}$ \\
\hline
\end{tabular}

Source: own study.

There has been and still is, a considerable diversity between adapted measures and time when they were put into place, thus there is a number of reasons why some countries have been more severely affected than others. The Government Stringency Index (GSI) is an index that demonstrates the strictness of government approach to COVID-19. It is a composite measure of nine metrics i.e., school and workplace closures, restrictions on public gatherings and cancellation of public events, public transport shutdown, stay-home requirements and restrictions on internal and international movements, and public information campaigns (Ritchie et al., 2020). The indexes are presented in Table 2.

Table 2. Comparison of the GSI in selected EU countries at crucial periods of the coronavirus pandemic

\begin{tabular}{|l|c|c|c|c|c|c|}
\hline \multicolumn{1}{|c|}{ Variable } & Belgium & GSI BE & France & GSI FR & Poland & GSI PL \\
\hline First confirmed case & $04 / 02$ & $\mathbf{1 1 . 1}$ & $24 / 01$ & $\mathbf{1 1 . 1}$ & $04 / 03$ & $\mathbf{1 1 . 1}$ \\
\hline Ban of gatherings $>\mathbf{1 0 0 0}$ people & $10 / 03$ & $\mathbf{1 9 . 4 4}$ & $10 / 03$ & $\mathbf{4 3 . 9 8}$ & $10 / 03$ & $\mathbf{2 5}$ \\
\hline Closure of public spaces & $12 / 03$ & $\mathbf{2 3 . 1 5}$ & $12-13 / 03$ & $\mathbf{4 3 . 9 8}$ & $12 / 03$ & $\mathbf{4 1 . 6 7}$ \\
\hline Only necessary everyday activities & $17 / 03$ & $\mathbf{5 0 . 9 3}$ & $17 / 03$ & $\mathbf{8 7 . 9 6}$ & $25 / 03$ & $\mathbf{5 7 . 4 1}$ \\
\hline Closed borders to non-essential travel & $20 / 03$ & $\mathbf{8 1 . 4 8}$ & $17 / 03$ & $\mathbf{8 7 . 9 6}$ & $09 / 04$ & $\mathbf{8 3 . 3 3}$ \\
\hline Mandatory masks & $12 / 08$ & $\mathbf{5 8 . 3 3}$ & $28 / 08$ & $\mathbf{4 8 . 1 5}$ & $16 / 04$ & $\mathbf{8 3 . 3 3}$ \\
\hline Days to lockdown from the first case & $\mathbf{4 2}$ & $\mathbf{-}$ & 53 & - & 21 & - \\
\hline First peak & $15 / 04$ & $\mathbf{8 1 . 4 8}$ & $18 / 04$ & $\mathbf{8 7 . 9 6}$ & $11 / 04$ & $\mathbf{8 3 . 3 3}$ \\
\hline Second wave onset & $04 / 09$ & $\mathbf{5 2 . 7 8}$ & $18 / 07$ & $\mathbf{4 6 . 3}$ & $09 / 09$ & $\mathbf{3 6 . 1 1}$ \\
\hline Second peak & $31 / 10$ & $\mathbf{5 6 . 4 8}$ & $3 / 11$ & $\mathbf{7 8 . 7}$ & $11 / 11$ & $\mathbf{7 1 . 3}$ \\
\hline
\end{tabular}

Source: (Ritchie et al., 2020).

Nevertheless, these are only the examples of undertaken measures to slow down the spread of the virus. It is very important to emphasize that this scenario will happen again in the future - we have been warned twice - as aforementioned, once in 2003 and then in 2012. Researchers are able to select viruses with potential to cause a pandemic, namely Nipah virus (Luby, 2013), H7N9 influenza A virus (CDC 018) and others (Fernandez-Montero et al., 2020). 


\section{RESEARCH METHODOLOGY}

Data were collected from the on-line database: https://covid.ourworldindata.org/data/owid-coviddata.xlsx, which demonstrate the daily number of new cases and deaths due to the COVID-19 pandemic. The forecast was based on a linear trend function and a 7-period moving average, using Statistica 13 software.

The following methods were used in the article - linear trend function and moving average (Hydzik \& Sobolewski, 2007; Zeliaś, Wanat \& Pawełek, 2020). The least squares method was used to estimate the parameters of the linear trend function. For the moving average, a 7-period moving average was used to predict new COVID-19 cases and new deaths in three selected European countries.

The analysis shows that the number of new cases is time-dependent for each country. The daily increase in the number of cases for Poland is $59 \pm 4$, for France $80 \pm 5$, while for Belgium the increase is $21 \pm 2$.

The trend matching coefficient for Poland was $48 \%$, France $42 \%$, and for Belgium $26 \%$. The coefficient of determination $\mathrm{R}^{2}$ is relatively high in relation to the data for Poland and France, while it is unsatisfactory in the case of Belgium. This may be due to relatively mild disease peaks in Poland and France, while the sharp increase in cases, reaching as much as 18,000 in Belgium. The parameters of the trend function were estimated using the least squares method for three selected European Union countries - Poland, France and Belgium. On their basis, forecasts for subsequent periods were made (the obtained results are presented in Table 3).

There was also calculated the differentiation of countries in terms of the number of new cases with the use of descriptive statistics - standard deviation and the coefficient of variation. For all three countries, the coefficient of variation is very high and amounts to $171 \%, 152 \%$ and $172 \%$, respectively for Poland, France and Belgium.

The analysis of the increase in the number of deaths shows that the number of new deaths is timedependent only for Poland. The daily increase in the number of people who died for Poland is $1 \pm 1$. Due to the lack of correlation between the increase in the number of deaths in France and Belgium, the forecast was calculated on the basis of a 7-period moving average. The results are shown in Table 3.

There were calculated also statistical measures describing the number of new deaths in the EU countries: Poland, France and Belgium. For all three countries, the coefficient of variability is very high and amounts to $171 \%, 123 \%$ and $126 \%$, respectively for Poland, France and Belgium.

\section{RESULTS AND DISCUSSION}

The results of forecasts of the number of new cases for the next 3 periods (days) for individual countries are presented in Table 3. The forecast results were obtained on the basis of the linear trend and with the use of a 7-period moving average. First, the number of new cases of COVID-19 was predicted, followed by the number of deaths. Figures 1, 2 and 3 show the results for three European Union countries: Poland, France and Belgium.

The results of the forecasts of the number of new deaths for the next 3 periods (days) for individual countries are presented in Table 4. Figures 4, 5 and 6 show the results for three European Union countries: Poland, France and Belgium.

Table 3. Country-specific COVID-19 new cases results

\begin{tabular}{|l|c|c|c|c|}
\hline \multicolumn{1}{|c|}{ Methods } & Period & Poland & France & Belgium \\
\hline \multirow{2}{*}{$\begin{array}{l}\text { Forecast based on a linear trend function - prepared } \\
\text { in the Statistica 13 program }\end{array}$} & Day 1 & 12624,08 & 20817,08 & 5379,85 \\
\cline { 2 - 5 } & Day 2 & 12683,17 & 20897,46 & 5401,39 \\
\cline { 2 - 5 } & Day 3 & 12742,26 & 20977,83 & 5422,92 \\
\hline \multirow{3}{*}{ Forecast based on a moving average } & Day 1 & 4106,02 & 6266,12 & 1144,78 \\
\cline { 2 - 5 } & Day 2 & 2730,31 & 4023,71 & 724,35 \\
\cline { 2 - 5 } & Day 3 & 1362,47 & 2040,10 & 361,22 \\
\hline
\end{tabular}

Source: own study. 
Table 4. Country-specific COVID-19 death forecast results

\begin{tabular}{|l|c|c|c|c|}
\hline \multicolumn{1}{|c|}{ Methods } & Period & Poland & France & Belgium \\
\hline \multirow{2}{*}{$\begin{array}{l}\text { Forecast based on a linear trend function - prepared } \\
\text { in the Statistica 13 program }\end{array}$} & Day 1 & 266,54 & 246,12 & 59,97 \\
\cline { 2 - 5 } & Day 2 & 267,8 & 246,37 & 59,94 \\
\cline { 2 - 5 } & Day 3 & 269,05 & 246,63 & 59,90 \\
\hline \multirow{3}{*}{ Forecast based on the moving average method } & Day 1 & 155,61 & 166,14 & 42,27 \\
\cline { 2 - 5 } & Day 2 & 103 & 107,71 & 26,9 \\
\cline { 2 - 5 } & Day 3 & 51,31 & 53,63 & 13,12 \\
\hline
\end{tabular}

Source: own study.

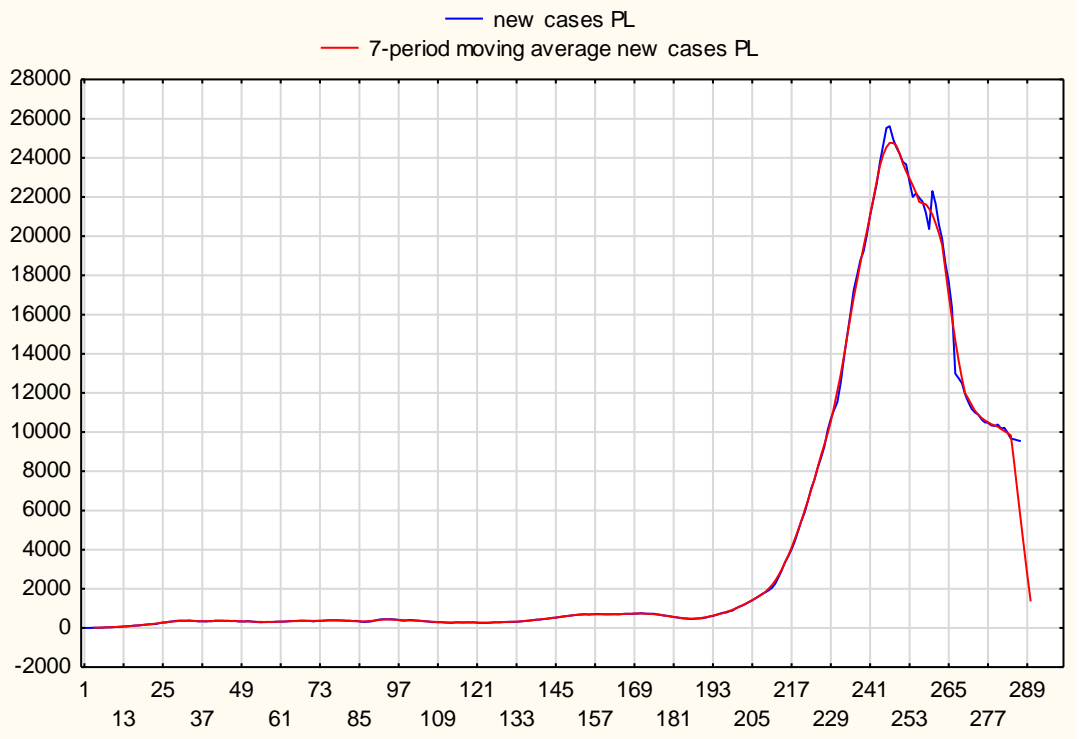

Figure 1. Forecast of new COVID-19 cases for Poland based on a 7-period moving average Source: own elaboration.

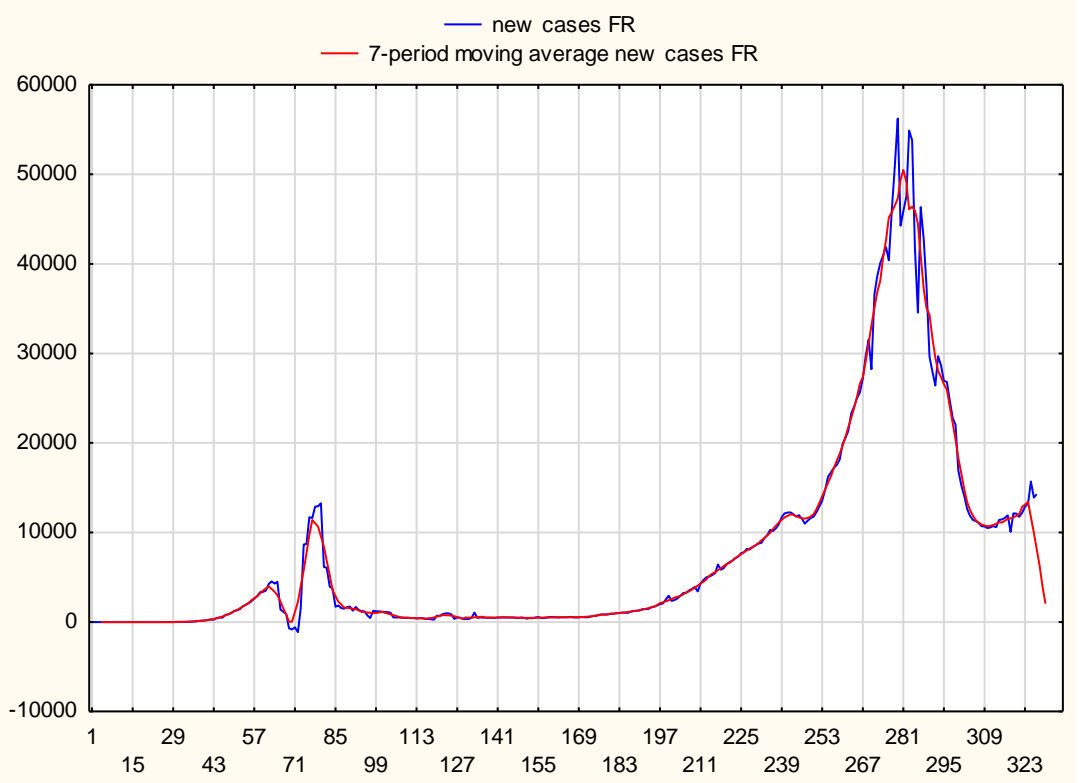

Figure 2. Forecast of new COVID-19 cases for France based on a 7-period moving average Source: own elaboration. 


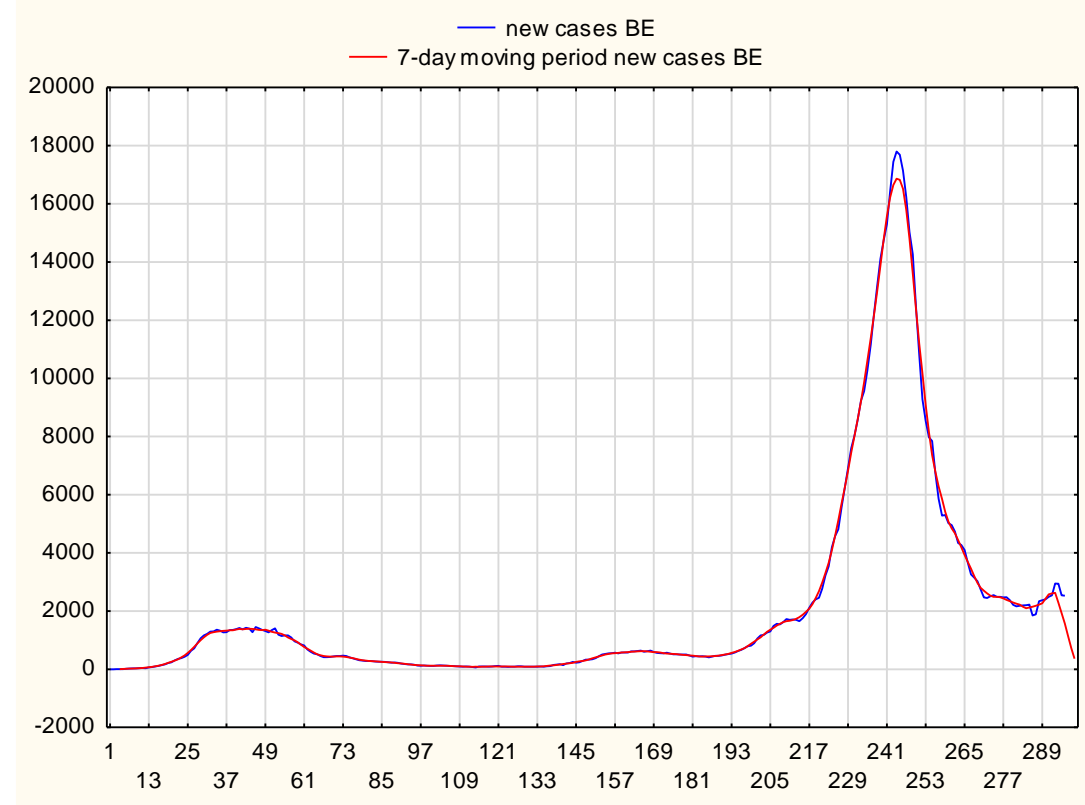

Figure 3. Forecast of new COVID-19 cases for Belgium based on a 7-period moving average Source: own elaboration.

In the following figures there are figures presenting the results of the forecast of new deaths due to COVID-19 for three European Union countries: Poland, France and Belgium.

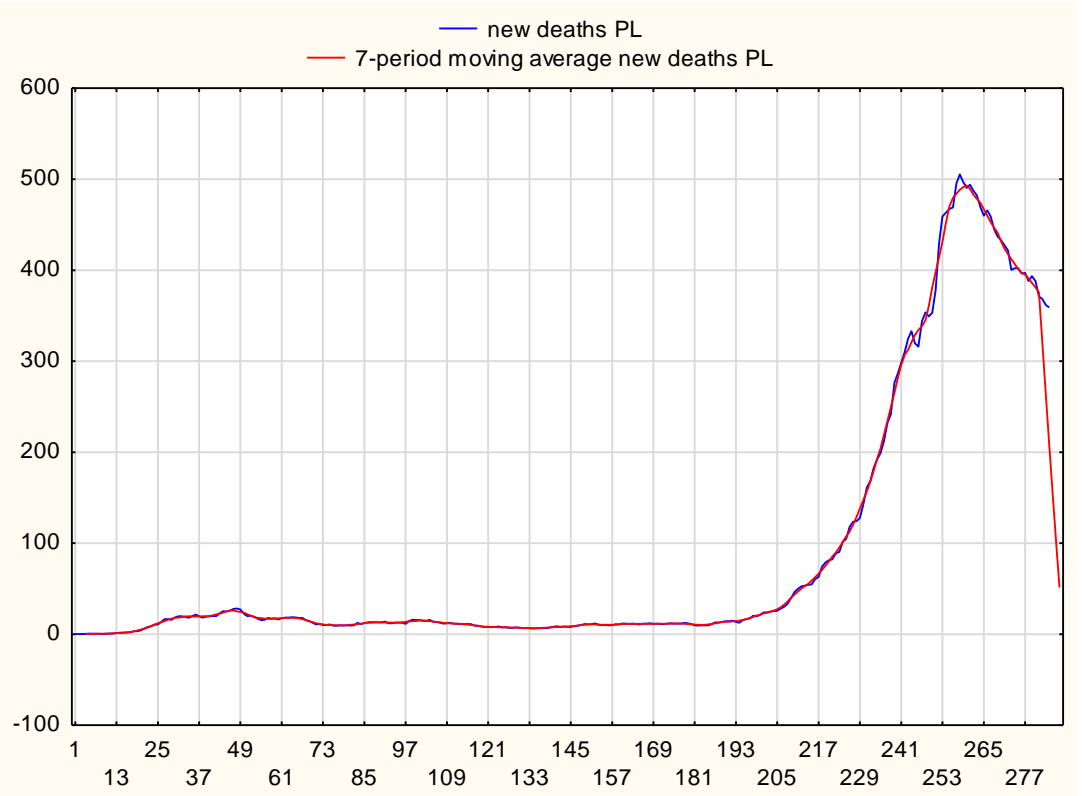

Figure 4. Forecast of new deaths due to COVID-19 for Poland based on a 7-period moving average Source: own elaboration. 


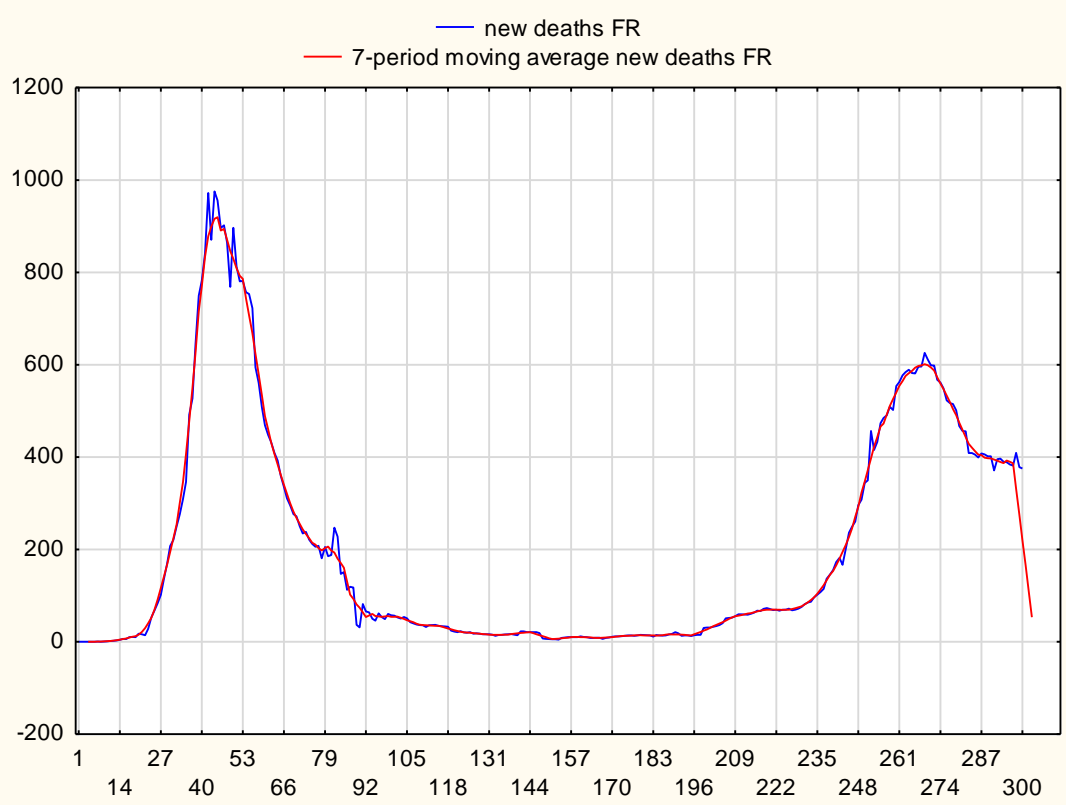

Figure 5. Forecast of new COVID-19 deaths for France based on a 7-period moving average Source: own elaboration.

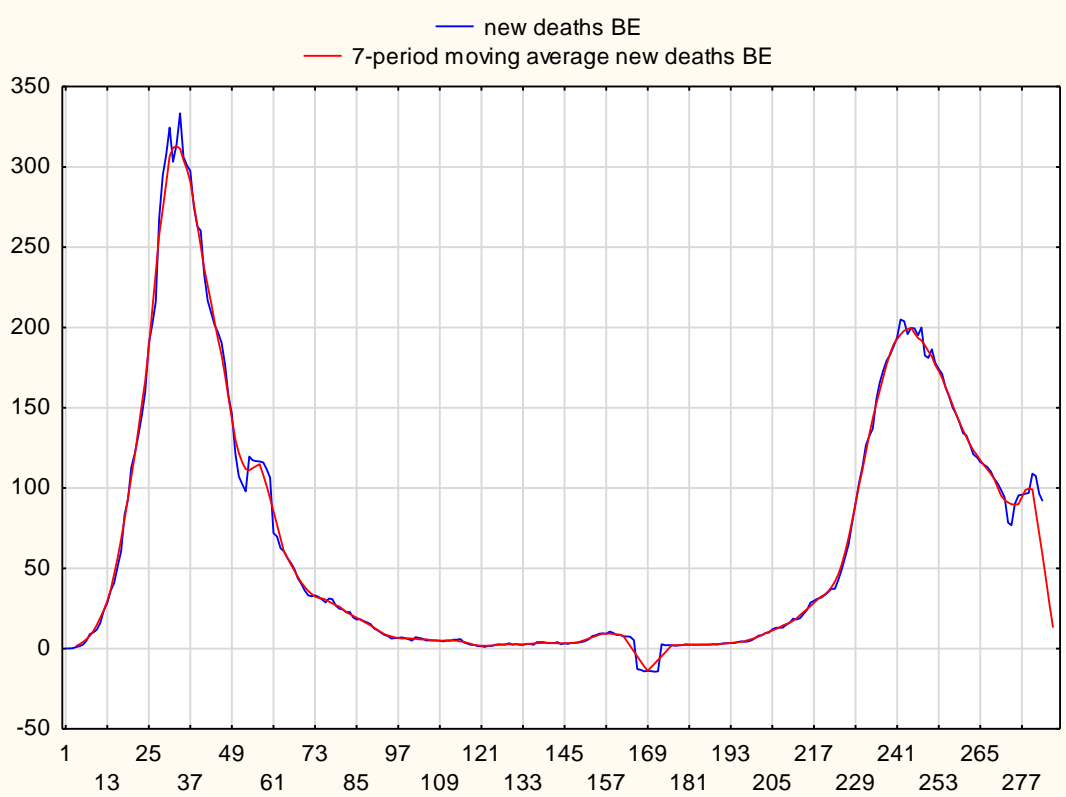

Figure 6. Forecast of new COVID-19 deaths for Belgium based on a 7-period moving average Source: own elaboration.

Moreover, the data show that Poland had the quickest response to COVID-19 among other studied countries with just 21 days from the first case to full lockdown, comparing to 42 days and 53 days for Belgium and France, respectively. One of the reasons of the second wave of the novel coronavirus pandemic was loosening the restrictions, whereas the GSI equalled 52.78, 46.3 and 36.11 for Belgium, France and Poland, respectively. Governments to regain control over the spread of SARS-CoV-2 have implemented restrictions one more time. The most stringent country during the second peak was France and the less one was Belgium. 


\section{CONCLUSIONS}

The article presents the results of the forecast, which made it possible to estimate the values of new cases and the number of deaths caused by the SARS-CoV-2 virus in selected European Union countries: Belgium, France and Poland. The forecast results were obtained on the basis of the linear trend and with the use of a 7-period moving average. Moreover, in the article were compared the values of the stringency index of selected European countries at the time of the onset of the peaks and with the overall impact of COVID-19 on the number of new cases and COVID-19-related deaths.

The increase in the number of new cases was similar for all three countries, with the most similar increase in cases between Poland and France (Table 3). In the case of the increase in deaths due to COVID-19, Poland stood out comparing to other countries - France and Belgium had two peaks in the number of deaths, which corresponds to two waves of the disease - the first in the first quarter of 2020 and the second at the turn of the third and fourth quarter 2020. In the case of Poland, the aforementioned restrictions introduced at the beginning of the pandemic allowed to avoid infections and deaths caused by the SARS-CoV-2 virus. Therefore, the coefficient of variation for Poland is much higher than for France and Belgium.

Based on the results obtained by China, where the pandemic ended after a year, it can be assumed that EU countries will also win the fight against Covid-19 at a similar time. From the obtained results, it can be concluded that the pandemic caused by the SARS-CoV-2 virus will end in 2021 in the analysed countries, about a year after the first case that appeared in Europe, provided that the vaccines are also effective against the mutated form of the virus. Summing up, it should be emphasized that the forecasting is erroneous and the values never obtained can be considered $100 \%$ certain. The data are difficult to interpret because they are often incomplete and released with a significant delay. Furthermore, the analysis can be unclear and unreliable due to the differences between specific country COVID-19 testing regimes.

Another issue that should be noted is the fact that EU governments should allocate more resources to health protection and improving the living conditions of the inhabitants of the European Union countries [Migała-Warchoł \& Sobolewski, 2020). In further studies which aim will be the analysis of the results of the third wave caused by the SARS-CoV-2 virus is planned to use the SIR model.

\section{REFERENCES}

Bedford, T. \& Hodcroft, E. (2021). Phylogeny of SARS-like betacoronaviruses including novel coronavirus (nCoV). GISAID Global Initiative on Sharing All Influenza Data. Retrieved from https://nextstrain.org/groups/blab/sars-like-cov on 13 January 2021.

CDC (2018). Asian Lineage Avian Influenza A(H7N9) Virus. Last reviewed on December 7, 2018. Centers for Disease Control and Prevention, National Center for Immunization and Respiratory Diseases (NCIRD). Retrieved from https://www.cdc.gov/flu/avianflu/h7n9-virus.htm on 1 February 2021.

Cheng, C., Barceló, J., Hartnett, A. S., Kubinec, R., \& Messerschmidt, L. (2020). COVID-19 Government Response Event Dataset (CoronaNet v.1.0). Nature Human Behaviour, 4(7), 756-768. https://doi.org/10.1038/s41562-020-0909-7

Chun, J.Y., Baek, G., \& Kim, Y. (2020). Transmission onset distribution of COVID-19. International journal of infectious diseases. IJID, vol. 99, 403-407. The official publication of the International Society for Infectious Diseases. https://doi.org/10.1016/j.ijid.2020.07.075

Esakandari, H., Nabi-Afjadi, M., Fakkari-Afjadi, J., Farahmandian, N., Miresmaeili, S. M., \& Bahreini, E. (2020). A comprehensive review of COVID-19 characteristics. Biological Procedures Online, 22, 19. https://doi.org/10.1186/s12575-020-00128-2

Fernandez-Montero, J. V., Soriano, V., Barreiro, P., de Mendoza, C., \& Artacho, M. Á. (2020). Coronavirus and other airborne agents with pandemic potential. Current Opinion in Environmental Science \& Health, 17, 4148. https://doi.org/10.1016/j.coesh.2020.09.001

Hydzik P., Sobolewski M. (2007). Komputerowa analiza danych społeczno-gospodarczych. Rzeszów: Oficyna Wydawnicza Politechniki Rzeszowskiej. 
Jiang, F., Deng, L., Zhang, L., Cai, Y., Cheung, C. W., \& Xia, Z. (2020). Review of the Clinical Characteristics of Coronavirus Disease 2019 (COVID-19). Journal of General Internal Medicine, 35(5), 1545-1549. https://doi.org/10.1007/s11606-020-05762-w

Kinnunen, J., Georgescu, I., Hosseini, Z., \& Androniceanu, A.-M. (2021). Dynamic indexing and clustering of government strategies to mitigate Covid-19. Entrepreneurial Business and Economics Review, 9(2), 7-19. https://doi.org/10.15678/EBER.2021.090201

Lipkind, T., \& Kitrar, L. (2021). The relationship of economic sentiment and GDP growth in Russia in light of the Covid-19 crisis. Entrepreneurial Business and Economics Review, 9(1), 7-29. https://doi.org/10.15678/EBER.2021.090101

Luby S. P. (2013). The pandemic potential of Nipah virus. Antiviral Research, 100(1), 38-43. https://doi.org/10.1016/j.antiviral.2013.07.011

Marjański, A., \& Sułkowski, Ł. (2021). Consolidation strategies of small family firms in Poland during Covid-19 crisis. Entrepreneurial Business and Economics Review, 9(2), 167-182. https://doi.org/10.15678/EBER.2021.090211

Marona, B., \& Tomal, M. (2020). The COVID-19 pandemic impact upon housing brokers' workflow and their clients' attitude: Real estate market in Krakow. Entrepreneurial Business and Economics Review, 8(4), $221-232$. https://doi.org/10.15678/EBER.2020.080412

Migała-Warchoł A., Sobolewski M., (2020). The influence of the economic situation on the socio-economic development in the European Union countries by means of the modified HDI index, Proceedings of the 3rd Annual Conference 'Technology transfer: innovative solutions in Social Sciences and Humanities', 30 April 2020 Tallinn, Estonia, 28-31.

Ritchie, H., Ortiz-Ospina, E., Beltekian, D., Mathieu, E., Hasell, J., Macdonald, B., Giattino, Ch., Appel, C., \& Roser, M. (2020). Policy Responses to the Coronavirus Pandemic. Research and data. Retrieved from https://ourworldindata.org/policy-responses-covid on 9 January 2021.

Szostak, M, \& Sułkowski, Ł. (2021). Identity crisis of artists during the Covid-19 pandemic and shift towards entrepreneurship. Entrepreneurial Business and Economics Review, 9(3). Ahead-of-Print.

Tyrrell, D. A., \& Bynoe, M. L. (1966). Cultivation of viruses from a high proportion of patients with colds. Lancet (London, England), 1(7428), 76-77. https://doi.org/10.1016/s0140-6736(66)92364-6

Velavan, Th.P., \& Meyer, Ch.G. (2021). The COVID-19 epidemic (nih.gov) [Accessed on-line: 08/01/2021]

Żak, M., \& Garncarz, J. (2020). Economic policy towards the challenges of the COVID-19 pandemic in selected European Union countries. International Entrepreneurship Review, 6(4), 21-34 https://doi.org/10.15678/IER.2020.0604.02

Zeliaś A., Wanat S., Pawełek B. (2020). Prognozowanie ekonomiczne. PWN: Warszawa

Zhou, P., Yang, XL., Wang, XG. et al. (2020). A pneumonia outbreak associated with a new coronavirus of probable bat origin. Nature, 579, 270-273. https://doi.org/10.1038/s41586-020-2012-7 


\section{Authors}

The contribution share of authors is equal and amounted to $50 \%$ for each of them.

\section{Aldona Migała-Warchoł}

PhD in Economics, Assistant Professor at the Quantitative Methods Department, Rzeszow University of Technology in Poland. Her main scientific interests concern the application of statistical analysis methods (including multidimensional statistical analysis) in aspects related to issues of quality and standard of human life (using survey data, measured on weak scales and data from statistical reports, measured on strong scales). Recently, her scientific interests cover the modelling of socio-economic development and its determinants in the European Union countries.

Correspondence to: Dr Aldona Migała-Warchoł, Quantitative Methods Department, Rzeszow University of Technology, Al. Powstańców Warszawy 12, 35-959 Rzeszów, Poland, e-mail: amigala@prz.edu.pl ORCID (1) http://orcid.org/0000-0002-9756-3402

\section{Monika Pichla}

PhD Student in Biology, Rzeszów University, Poland. Her main scientific interests involve the screening for novel anti- cancer and neurodegenerative drugs and their future application in medicine. Privately, she is interested in the news of pharmaceutical industry and in clinical psychology.

Correspondence to: Mgr Monika Pichla, Laboratory of Analytical Biochemistry, Institute of Food Technology and Nutrition, College of Natural Sciences, Rzeszow University, ul. Zelwerowicza 4, 35-601 Rzeszów, Poland, e-mail: monika.pichla@outlook.com

ORCID 이 http://orcid.org/0000-0001-7469-260X

\section{Acknowledgements and Financial Disclosure}

The authors would like to thank the anonymous referees for their useful comments, which allowed to increase the value of this article. A special appreciation goes to prof. dr hab. Tadeusz Grabiński for his support and guidelines.

\section{Conflict of Interest}

The authors declare that there is no conflict of interest regarding the publication of this paper.

\section{Copyright and License}

This article is published under the terms of the Creative Commons

Attribution - NoDerivs (CC BY-ND 4.0) License

http://creativecommons.org/licenses/by-nd/4.0/ 